\title{
THE IMPLEMENTATION OF COOPERATIVE LEARNING MODEL OF CONCEPT SENTENCE TO IMPROVE PANTUN SKILL WRITING
}

\author{
Nur Esti Handayani, Endang Sri Markamah, Muhammad Ismail Sriyanto \\ Universitas Sebelas Maret \\ nurestihandayani@gmail.com
}

\section{Article History}

accepted 09/07/2018

approved 01/08/2018

published 17/09/2018

\section{Keywords}

cooperative learning model, concept sentence, pantun writing skill

\begin{abstract}
The purpose of this research to improve pantun writing skill through Cooperative Learning Model of Concept Sentence in the fourth grade one of Elementary School in Surakarta the academic year 2017/2018. The type of this research is Classroom Action Research which consists of three cycles. Each cycle consists of four stages, namely planning, action, observation, and reflection. The subjects in this study were grade IV teacher and 21 IV graders one of Elementary School in Surakarta the academic year 2017/2018. The data collection techniques are conducted through interview, observation, test, and documentation. The data validity uses content validity, source triangulation, and technical triangulation. The data were analyzed by comparative descriptive technique and interactive analysis model, consisting of three steps, namely data collection, data presentation, and conclusion or verification. The result of research shows the improvement applying of Cooperative Learning Model of Concept Sentence was able to improve pantun writing skill the fourth grade one of Elementary School in Surakarta the academic year of 2017/2018.
\end{abstract}

Social, Humanities, and Education Studies (SHEs): Conference Series https://jurnal.uns.ac.id/shes 


\section{PENDAHULUAN}

Bahasa merupakan salah satu alat yang digunakan seseorang untuk berkomunikasi dan berinteraksi dalam kegiatan sehari-hari. Penggunaan bahasa yang baik dan benar diperoleh di bangku sekolah melalui proses pembelajaran Bahasa Indonesia. Mata pelajaran Bahasa Indonesia merupakan salah satu pembelajaran yang harus disampaikan dengan baik, karena bahasa menjadi salah satu alat komunikasi untuk menyampaikan pesan kepada orang lain.

Salah satu materi Bahasa Indonesia yang dipelajari adalah keterampilan menulis. Keterampilan menulis merupakan keterampilan terakhir dan sulit untuk dikuasai siswa. Javed \& Nazli. S. (2013) menyatakan bahwa menulis sebagai salah satu dari empat keterampilan dasar. Siswa belajar berkomunikasi melalui bentuk tertulis untuk berinteraksi dengan orang lain di tingkat sekolah. Keterampilan menulis lebih rumit dari pada keterampilan bahasa lainnya.

Menulis merupakan kegiatan menuangkan ide ke dalam bentuk tulisan yang berisi pesan untuk pembeaca. Keterampilan menulis didapatkan melalui latihan yang rutin. Suparno dan Yunus (2008) mengemukakan bahwa seseorang enggan untuk menulis dikarenakan tidak mengetahui tujuan dia menulis, merasa tidak berbakat untuk menulis, dan tidak tahu bagaimana cara menulis. Hal tersebut berpengaruh terhadap rendahnya minat siswa belajar menulis, terutama menulis dalam bentuk karya sastra.

Kompetensi Dasar (SK) menulis yang harus dikuasai oleh siswa salah satunya adalah keterampilan menulis pantun anak dengan berbagai tema.Untuk mencapai hal tersebut guru berperan penting dalam membimbing siswa melalui penerapan model pembelajaran yang sesuai dengan materi yang diajarkan. Siti Hajar Che (2013) mengemukakan bahwa idea yang terungkap di dalam bait-bait pantunadalah bersifat berat dan series tetapi digayakan, diragam, di lenggok dan disampaikan dalam bentukyang ringan dan mudah, namun mesejnya amat mendalam, signifikan dan penuh bermakna. Pendapat tersebut sejalan dengan Mihardja (2012) yang berpendapat bahwa pantun adalah salah satu jenis puisi lama yang telah dikenal dalam berbagai bahasa-bahasa Nusantara. Peran guru sangat berpengaruh dalam menjadikan keterampilan menulis pantun menjadi menarik bagi siswa.

Berdasarkan hasil wawancara dengan guru kelas IV dan observasi di salah satu SD Surakarta diperoleh informasi bahwa kemampuan siswa dalam keterampilan menulis pantun masih rendah. Beberapa siswa masih kesulitan menuangkan ide-ide ke dalam bentuk tulisan khususnya pantun. Hal tersebut dikarenakan pemilihan dan penggunaan model pembelajaran yang kurang mendorong siswa untuk bersikap aktif dan kreatif, dalam proses pembelajaran guru jarang melakukan diskusi kelompok, penggunaan media yang belum sesuai dengan materi pembelajaran, dan penguasaan kosa-kata siswa yang masih terbatas. Berdasarkan guru kelas permasalahan utama yang dihadapi siswa dalam menulis pantun adalah menuangkan ide-ide dan menyusun kata ke dalam bentuk tulisan.

Sedangkan hasil wawancara dengan siswa kelas IV di salah satu SD Negeri Surakarta tahun ajaran 2017/2018 diperoleh informasi bahwa Bahasa Indonesia merupakan salah satu mata pelajaran yang disukai siswa khususnya materi menulis pantun. Meskipun siswa menyukai pembelajaran menulis pantun, masih banyak siswa yang belum bisa membuat pantun utuh yang sesuai dengan syarat-syaratnya. Siswa kesulitan dalam membuat sajak silang pada akhiran pantun.

Uji pratindakan diperoleh data bahwa dari 21 siswa terdapat 6 siswa yang nilainya mencapai sama dengan atau di atas Kriteria Ketuntasan Minimal (KKM). Hal tersebut menunjukkan bahwa ketuntasan klasikal baru mencapai 29\%, masih terdapat 15 siswa atau $71 \%$ memperoleh nilai di bawah KKM. Nilai KKM untuk keterampilan menulis pantun adalah 70. Dengan demikian, keterampilan menulis pantun siswa masih rendah. Berdasarkan wawancara, observasi, dan hasil tes pratindakan, maka 
keterampilan menulis pantun siswa kelas IV di salah satu SD Negeri Surakarta tahun ajaran 2017/2018 perlu ditingkatkan.

Usaha yang dilakukan untuk meningkatkan keterampilan menulis pantun siswa dengan menerapkan model pembelajaran yang tepat dan sesuai dengan materi. Model pembelajaran yang dapat digunakan yaitu model pembelajaran Concept Sentence.

Shoimin (2014) menyatakan bahwa model pembelajaran Concept Sentence adalah model pembelajaran yang dilakukan dengan memberikan siswa kartu-kartu yang berisi kata kunci. Sejalan dengan pendapat tersebut, Munirah (2017) mengemukakan bahwa model pembelajaran Concept Sentence adalah model pembelajaran yang diarahkan pada pembelajaran bahasa dengan menggunakan kata kunci. Kartu-kartu yang berisi kata kunci tersebut dikembangkan menjadi sebuah kalimat. Salah satu materi yang dapat diterapkan degan model pembelajaran ini adalah keterampilan menulis pantun, sehingga penerapan model pembelajaran Concept Sentence dapat digunakan sebagai solusi meningkat-kan keterampilan menulis pantun.

Adapun langkah-langkah penerapan model pembelajaran Concept Sentence menurut Huda (2017) sebagai berikut: 1) guru menyampaikan kompetensi yang hendak dicapai, 2) guru menyajikan materi pembelajaran secukupnya, 3) guru membentuk kelompok heterogen yang jumlah anggotanya kurang lebih empat siswa, 4) guru menyajikan beberapa kata kunci sesuai dengan materi yang disajikan, 5) setiap kelompok membuat kalimat dengan menggunakan minimal empat kata kunci setiap kalimatnya, 6) hasil diskusi kelompok didiskusikan kembali secara pleno dipandu guru, 7) siswa dibantu oleh guru memberikan kesimpulan.

Berdasarkan langkah-langkah pembelajaran tersebut, bahwa penerapan model pembelajaran Concept Sentence dapat meningkatkan antusias, motivasi, keaktifan serta kreativitas siswa terhadap pembelajaran menulis pantun. Hal tersebut berdampak terhadap peningkatan nilai keterampilna menulis pantun. Selain itu, model pembelajaran Concept Sentence memiliki kelebihan dapat meningkatkan kreatifitas siswa, meningkatkan keaktifan siswa, meningkatkan kerjasama dalam belajar kelompok, mendorong pemahaman siswa, serta mendorong siswa bersikap kompetitif. Model pembelajaran Concept Sentence dirancang menyerupai permainan kata kunci yang menarik dan menyenangkan, sehingga siswa tidak merasa bosan selama mengikuti pembelajaran. Model pembelajaran Concept Sentence dengan menggunakan kata kunci dapat merangsang siswa untuk menuangkan idenya ke dalam bentuk tulisan berupa pantun. Kata kunci yang telah disediakan digunakan untuk membentuk sajak silang pada pantun.

Berdasarkan uraian di atas, model pembelajaran Concept Sentence dapat diterapkan dalam pembelajaran menulis pantun di kelas IV SD Negeri Purwotomo No. 97 Surakarta. Kesesuaian materi pembelajaran dengan model pembelajaran adalah langkah-langkah pembelajaran yang menggunakan kartu kata kunci dengan menulis pantun. Kartu kata kunci yang telah disediakan dapat digunakan sebagai acuan dalam membuat akhiran pantun. Dalam penerapan model pembelajaran Concept Sentence siswa diajak bermain kartu kata kunci yang dikembangkan menjadi kalimat dalam bentuk pantun.

\section{METODE}

Pendekatan penelitian ini adalah kualitatif. Jenis penelitian yang digunakan adalah Penelitian Tindakan Kelas (PTK) dengan melalui empat tahap, yaitu tahap perencanaan, tahap pelaksanaan tindakan, tahap observasi, dan tahap refleksi. Penelitian ini dilakukan dalam tiga siklus. Data yang diperlukan dalam penelitian tindakan kelas meliputi data kuantitatif dan data kualitatif (Iskandar, 2012: 64). Data kuantitatif dalam penelitian ini adalah hasil nilai tes keterampilan menulis pantun sebelum dan sesudah penerapan model pembelajaran Concept Sentence. Sementara 
itu, data kualitatif dalam penelitian ini yaitu informasi tentang tingkat keterampilan menulis pantun sebelum dan sesudah penerapan model pembelajaran Concept Sentence, observasi aktivitas siswa dalam mengikuti pembelajaran dengan menenerapkan model pembelajaran Concept Sentence, hasil kinerja guru dalam pembelajaran dengan menerapkan model pembelajaran Concept Sentence, serta kendala-kendala dalam pembelajaran dengan menerapkan model pembelajaran Concept Sentence untuk meningkatkan keterampilan menulis pantun. Sumber data dalam penelitian ini adalah guru, siswa kelas IV, data nilai sebelum tindakan, lembar pengamatan, tes hasil belajar siswa. Teknik pengumpulan data melalui wawancara, observasi, tes, dan dokumentasi. Teknik validitas data penelitian ini menggunakan validitas isi, triangulasi sumber, dan triangulasi teknik. Analisis data menggunakan teknik deskriptif komparatif dan model interaktif yang terdiri dari empat tahap, yaitu pengumpulan data, reduksi data, penyajian data, dan penarikan kesimpulan.

\section{HASIL DAN PEMBAHASAN}

Sebelum pelaksanaan tindakan peneliti melakukan wawancara, observasi, dan tes untuk mengetahui kondisi awal dalam pembelajaran menulis pantun. Berdasarkan hasil wawancara, observasi, dan tes pratindakan, diketahui bahwa nilai keterampilan menulis pantun siswa kelas IV SD Negeri Purwotomo No. 97 Surakarta masih rendah. Hal ini terbukti banyak siswa yang belum mencapai Kriteria Ketuntasan Minimal (KKM) yaitu $\geq 70$. Rendahnya nilai keterampilan menulis pantun dapat dilihat pada Tabel 1 berikut:

\begin{tabular}{|c|c|c|c|c|c|}
\hline No & Interval & $\begin{array}{l}\text { Frekuensi } \\
\text { (fi) }\end{array}$ & $\begin{array}{l}\text { Nilai tengah } \\
\text { (xi) }\end{array}$ & fi.xi & $\begin{array}{c}\text { Presentase } \\
(\%)\end{array}$ \\
\hline $\begin{array}{c}1 . \\
2 . \\
3 . \\
4 . \\
5 . \\
\text { jumlah }\end{array}$ & $\begin{array}{l}29-39 \\
40-50 \\
51-61 \\
62-72 \\
73-83\end{array}$ & $\begin{array}{c}6 \\
2 \\
2 \\
5 \\
6 \\
21 \\
\text { Skor rat } \\
\text { Ketuntasa } \\
\text { Nilai } \\
\text { Nilai te }\end{array}$ & 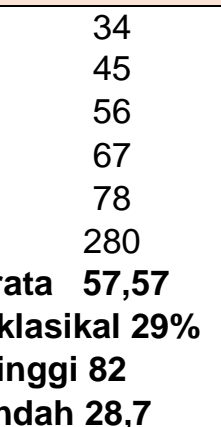 & $\begin{array}{c}204 \\
90 \\
112 \\
335 \\
468 \\
1209\end{array}$ & $\begin{array}{c}28,57 \\
9,52 \\
9,52 \\
23,81 \\
28,58 \\
100\end{array}$ \\
\hline
\end{tabular}

Berdasarkan Tabel 1, diperoleh informasi bahwa nilai rata-rata kelas tahap pratindakan yaitu 57,57 . Sebanyak 11 siswa (29\%) dari 21 siswa belum mencapai nilai $\mathrm{KKM} \geq 70$, sisanya 6 (71\%) siswa nilainya telah mencapai KKM $\geq 70$. Proses pembelajaran pratindakan masih belum berhasil dalam meningkatkan keterampilan menulis pantun. Maka, diperlukan tindakan untuk meningkatkan nilai keterampilan menulis pantun dengan penerapan model pembelajaran Concept Sentence.

Pelaksanaan tindakan meningkatkan keterampilan menulis pantun dengan menerapkan model pembelajaran Concept Sentence menunjukkan adanya peningkatan pada siklus I terhadap kinerja guru, observasi aktivitas siswa, dan hasil tes keterampilan menulis pantun pada setiap akhir pertemuan. Peningkatan hasil tes keterampilan menulis pantun pada siklus I dapat dilihat pada Tabel 2 berikut: 
Tabel 2. Distribusi Nilai Keterampilan Menulis Pantun Siklus I

\begin{tabular}{|c|c|c|c|c|c|}
\hline No & Interval & $\begin{array}{l}\text { Frekuensi } \\
\text { (fi) }\end{array}$ & $\begin{array}{l}\text { Nilai tengah } \\
\text { (xi) }\end{array}$ & fi.xi & $\begin{array}{c}\text { Presentase } \\
\text { (\%) }\end{array}$ \\
\hline 1. & $30-39$ & 2 & 34,5 & 69 & 9,52 \\
\hline 2. & $40-49$ & 1 & 44,5 & 44,5 & 4,76 \\
\hline 3. & $50-59$ & 2 & 54,5 & 109 & 9,52 \\
\hline 4. & $60-69$ & 7 & 64,5 & 451,5 & 33,34 \\
\hline 5. & $70-79$ & 9 & 74,5 & 670,5 & 42,86 \\
\hline jumlah & & 21 & 272,5 & 1344,5 & 100 \\
\hline \multicolumn{6}{|c|}{$\begin{array}{c}\text { Skor rata-rata } 64 \\
\text { Ketuntasan klasikal } 43 \% \\
\text { Nilai tetinggi } 82 \\
\text { Nilai terendah } 30\end{array}$} \\
\hline
\end{tabular}

Berdasarkan Tabel 2, diperoleh data bahwa nilai rata-rata kelas siklus I adalah 64. Siswa yang mendapatkan nilai sama dengan atau di atas KKM $(\geq 70)$ sebanyak 9 siswa (43\%), sedangkan 12 siswa (57\%) nilainya di bawah KKM ( $\geq 70)$. Data tersebut membuktikan bahwa terjadi peningkatan hasil nilai keterampilan menulis pantun dari pratindakan ke siklus I. Peningkatan siklus I terjadi pada kinerja guru dan observasi aktivitas siswa. Guru telah mampu mengelola kelas dengan menerapakan model pembelajaran Concept Sentence serta siswa lebih antusias, aktif dan kreatif dalam pembelajaran. Berdasarkan data siklus I ketuntasan klasikal (43\%) belum mencapai indikator kinerja penelitian (85\%). Penelitian dilanjutkan ke siklus II untuk direfleksi dan diperbaiki kekurangan pada siklus I.

Tindakan siklus II dengan penerapan model pembelajaran Concept Sentence, nilai keterampilan menulis pantun menngalami peningkatan. Hasil penelitian siklus II dapat dilihat pada Tabel 3 berikut ini:

\begin{tabular}{|c|c|c|c|c|c|}
\hline No & Interval & $\begin{array}{l}\text { Frekuensi } \\
\text { (fi) }\end{array}$ & $\begin{array}{l}\text { Nilai tengah } \\
\text { (xi) }\end{array}$ & fi.xi & $\begin{array}{c}\text { Presentase } \\
(\%)\end{array}$ \\
\hline $\begin{array}{c}1 . \\
2 . \\
3 . \\
4 . \\
5 . \\
\text { jumlah }\end{array}$ & $\begin{array}{l}55-63 \\
64-72 \\
73-81 \\
82-90 \\
91-99\end{array}$ & $\begin{array}{c}3 \\
1 \\
3 \\
5 \\
9 \\
21 \\
\text { Skor ra } \\
\text { Ketuntase } \\
\text { Nilai } \\
\text { Nilai t }\end{array}$ & $\begin{array}{c}59 \\
68 \\
79 \\
86 \\
95 \\
387 \\
\text { rata } 84,1 \\
\text { klasikal } 86 \% \\
\text { inggi } 96 \\
\text { endah } 55\end{array}$ & $\begin{array}{c}177 \\
68 \\
237 \\
430 \\
855 \\
1767\end{array}$ & $\begin{array}{c}14,29 \\
4,76 \\
14,29 \\
23,81 \\
42,85 \\
100\end{array}$ \\
\hline
\end{tabular}

Berdasarkan Tabel 3 diperoleh informasi bahwa hasil nilai keterampilan menulis pantun mengalami peningkatan dari siklus I ke siklus II. Siklus II nilai rata-rata kelas sebesar 84,1 . Sebanyak 18 siswa (86\%) telah mencapai nilai sama dengan atau di atas KKM $(\geq 70)$, sedangkan 3 siswa (14\%) masih belum mencapai KKM $(\geq 70)$. Ketuntasan klasikal siklus II yaitu $86 \%$. Maka, indikator kinerja penelitian (85\%) telah tercapai. Namun, tindakan masih perlu dilanjutkan ke tahap siklus berikutnya dikarenakan perolehan ketuntasan klasikal masih minim dari indikator kinerja penelitian (85\%). Peningkatan siklus II juga terjadi pada kinerja guru dan observasi aktivitas siswa. Kinerja guru siklus II semakin menguasai kelas dengan penerapan model pembelajaran Concept Sentence. Siswa semakin aktif, semangat, dan kreatif dalam mengikuti proses pembelajaran. 
Setelah tindakan siklus II pembelajaran keterampilan menulis pantun dengan penerapan model pembelajaran Concept Sentence, hasil tes keterampilan menulis pantun terjadi peningkatan pada siklus III. Peningkatan tersebut dapat dilihat pada Tabel 4 berikut ini:

\begin{tabular}{|c|c|c|c|c|c|}
\hline No & Interval & $\begin{array}{l}\text { Frekuensi } \\
\text { (fi) }\end{array}$ & $\begin{array}{l}\text { Nilai tengah } \\
\text { (xi) }\end{array}$ & fi.xi & $\begin{array}{c}\text { Presentase } \\
(\%)\end{array}$ \\
\hline $\begin{array}{c}1 . \\
2 . \\
3 . \\
4 . \\
5 . \\
\text { jumlah }\end{array}$ & $\begin{array}{l}52-60 \\
61-69 \\
70-78 \\
79-87 \\
88-96\end{array}$ & $\begin{array}{c}2 \\
0 \\
1 \\
2 \\
16 \\
\mathbf{2 1} \\
\text { Skor rat } \\
\text { Ketuntasa } \\
\text { Nilai } \\
\text { Nilai t }\end{array}$ & $\begin{array}{l}\quad 56 \\
65 \\
74 \\
83 \\
92 \\
\quad 370 \\
\text { rata } 86,86 \\
\text { klasikal } 90 \% \\
\text { inggi } 95 \\
\text { endah } 52\end{array}$ & $\begin{array}{c}112 \\
0 \\
74 \\
166 \\
1472 \\
1824\end{array}$ & $\begin{array}{c}9,52 \\
0 \\
4,76 \\
9,52 \\
76,2 \\
100\end{array}$ \\
\hline
\end{tabular}

Berdasarkan Tabel 4, diperoleh informasi bahwa nilai keterampilan menulis pantun sisklus III mengalami peningkatan dari hasil siklus II. Nilai rata-rata kelas keterampilan menulis pantun siklus III adalah 86,86 . Siswa yang mendapatkan nilai sama dengan atau di atas KKM ( $\geq 70)$ sebanyak 19 siswa (90\%), sedangkan 2 siswa $(10 \%)$ masih belum mencapai nilai KKM $(\geq 70)$. Ketuntasan klasikal siklus III yaitu $90 \%$, maka indikator kinerja penelitian (85\%) terlah tercapai. Peningkatan terjadi pada kinerja guru dan observasi aktivitas siswa. Guru semakin menguasai kelas dan materi dengan penerapan model pembelajaran Concept Sentence. Pembelajaran berlangsung menyenangkan dan kondusif. Siswa antusias dan aktif dalam kegiatan pembelajaran menulis pantun. Siswa juga semakin kreatif dalam menuangkan ide ke dalam ben-tuk tulisan khususnya pantun.

Hal tersebut menunjukkan bahwa terjadi peningkatan nilai keterampilan menulis pantun antarsiklus. Berdasarkan data tersebut, terbukti bahwa hasil nilai rata-rata tes evaluasi keterampilan menulis pantun pratindakan yaitu sebesar 57,57 , meningkat pada siklus I menjadi 64, meningkat pada siklus II menjadi 84,1 , dan meningkat pada siklus III menjadi 86,86.

Peningkatan juga terjadi pada ketuntasan klasikal. Pada tahap pratindakan ketuntasan klasikal yang diperoleh yaitu 43\%. Pada siklus I, ketuntasan klasikal meningkat menjadi $43 \%$. Pada siklus II, terjadi peningkatan ketuntasan klasikal yaitu meningkat menjadi $86 \%$. Pada siklus III, ketuntasan klasikal meningkat menjadi $90 \%$. Maka, indikator kinerja penelitian (85\%) telah tercapai. Sehingga, tindakan dihentikan pada siklus III.

Penerapan model pembelajaran Concept Sentence dalam pembelajaran menulis pantun juga berdampak positif terhadap kinerja guru dan aktivitas siswa. Guru lebih menguasai kelas dan materi pembelajaran serta mampu menumbuhkan suasana pembelajaran yang menyenangkan sehingga siswa antusias dan semangat mengikuti kegiatan pembelajaran.

Siswa lebih aktif, antusias, dan kreatif dalam mengikuti pembelajaran. Siswa dapat bekerja sama dalam kegiatan diskusi kelompok. Siswa mulai berpikir kritis dan menuangkan idenyan ke dalam bentuk tulisan. Hal tersebut sesuai dengan pendapat Huda (2017) yang menyatakan kelebihan model pembelajaran Concept Sentence antara lain: meningkatkan semangat belajar siswa, membantu terciptanya suasana pembelajaran yang kondusif, memuculkan kegembiraan dalam pembelajaran, 4)mendorong dan mengembangkan proses berpikir kreatif, mendorong siswa untuk 
memandang sesuatu dari sudut pandang yang berbeda, memuculkan kesadaran untuk berubah menjadi lebih baik, memperkuat kesadaran diri, lebih memahami kata kunci dari materi pokok pelajaran, dan siswa yang lebih pandai mengajari siswa yang kurang pandai.

Penerapan model pembelajaran Concept Sentence pada pembelajaran keterampilan menulis pantun dapat meningkatkan aktivitas siswa dan kinerja guru pada setiap siklusnya. Hal tersebut dapat dilihat adanya peningkatan aktivitas siswa antarsiklus. Pada siklus I perolehan rata-rata skor aktivitas siswa adalah 2,45, pada siklus II meningkat menjadi 2,74, pada siklus III mengalami peningkatan menjadi 3,68.

\section{SIMPULAN}

Penerapan model pembelajaran Concept Sentence dapat meningkatkan kinerja guru serta aktivitas siswa yang meliputi aktivitas mendengar, berbicara, membaca, menulis, dan aktivitas mental pada setiap siklus. Penerapan model pembelajaran Concept Sentence dapat meningkatkan nilai keterampilan menulis pantun siswa kelas IV SD Negeri Purwotomo No. 97 Surakarta tahun ajaran 2017/2018. Persentase ketuntasan klasikal mengalami peningkatan pada setiap siklusnya. Persentase ketuntasan klasikal nilai keterampilan menulis pantun pada uji pratindakan yaitu $29 \%$, siklus I meningkat menjadi yaitu $43 \%$, siklus II meningkat menjadi $86 \%$, dan meningkat pada siklus III menjadi $90 \%$. Hal ini dikarenakan penerapan langkah-langkah model pembelajaran Concpet Sentence yang dirancang menyeruapai permainan serta disesuaikan dengan kondisi tempat penelitian. Implikasi teoritis penelitian ini adalah penerapan model pembelajaran Concept Sentence dapat meningkatkan hasil nilai keterampilan menulis pantun pada siswa kelas IV. Hasil penelitian ini dapat digunakan untuk bahan kajian referensi pada penelitian sejenis mengenai model pembelajaran Concept Sentence dan keterampilan menulis pantun. Secara teoritis proses pembelajaran berpengaruh terhadap hasil yang diperoleh siswa. Oleh karena itu, perlu adanya pengembangan dalam penelitian lain sehingga ditemukan model, metode, maupun strategi pembelajaran untuk meningkatkan proses dan hasil pembelajaran yang lebih baik.

\section{DAFTAR PUSTAKA}

Huda, M. (2017). Model-model Pengajaran dan Pembelajarn. Yogyakarta: Pustaka Pelajar.

Javed, M, Juan, W, X,.\&Nazli.S. (2013). A Study of Student's Assesmentin Writing Skills of the English Language.International Journal of Instruction.Vol. 6 No. 2. Diperoleh 26 februari 2018 dari www.e-iji.net.

Man, Siti HajarChe. (2013). Kelestarian Pantun: Rencah dan Leluhur Bangsa Dulu, Kini, dan Selamanya. International Journal of The Malay World and Civilisation (Iman) I(I). 75-81. Diperoleh pada 26 Februari 2018 dari http://journalarticle.ukm.my/6395/1/IMAN1_6.

Mihardja, Ratih. (2012). Sastra Indonesia. Jakarta: Laskar Aksara.

Munirah. (2017). The Effectiveness of Concept Sentence Model toward Writing Skills of Persuasive Paragraph Volume 7, Number 2. Theory and Pratice in Language Studies Universitas Muhammadiyah Makasar. Diperoleh pada 26 Februari 2018 dari

http://www.academypublication.com/ojs/index.php/tpls/article/view/tpls0702112 $121 \& \mathrm{hl}=\mathrm{en}-\mathrm{ID}$

Shoimin, A. (2014). 68 Model Pembelajaran inovatif Dalam Kurikulum 2013. Yogyakarta: AR-RUZZ MEDIA.

Suparno dan M. Yunus. (2008). Keterampilan Dasar Menulis. Jakarta: Universitas Terbuka. 